\title{
Manajemen Pondok Pesantren Asy-syamsiyah Denpasar Bali (Kompetensi Guru dan Bimbingan Potensi Santri)
}

\author{
Hafidul Muhsin ${ }^{1}$, Nengah Bawa Atmaja ${ }^{2}$, Nyoman Dantes ${ }^{3}$ \\ 1,2,3 Managemen Pendidikan, Program Pascasarjana, Universitas Pendidikan Ganesha, Indonesia
}

Keywords: management; competence of teachers; potential santri

\section{Kata kunci:}

managemen;

kompetensi guru;

potensi santri

\begin{abstract}
The research aims to determine the strategy used Pondok Pesantren Asy-Syamsiyah in overcoming the problems that exist, to determine the increase in knowledge management systems and skills of teachers Pondok Pesantren Asy-Syamsiyah, to determine the role of Ash-Syamsiyah boarding school in guidance santri. This study uses qualitative research. The data obtained in this research through direct observation of researchers examine and follow the activities at the Pondok Pesantren As-Syamsiyah Denpasar Bali, interview the researchers interviewed teachers, administrators, and students is in boarding school, from books to documents in the administration there in the office, photos and other documents. The study yielded that the competency of teachers is lacking with the lack of training and education boarding school teachers, teachers who lack formal education can affect the management manage. In developing the potential of students, teachers provide training in accordance with the talents of students outside of active learning.
\end{abstract}

\begin{abstract}
Abstrak:Penelitian bertujuan untuk mengetahui strategi yang digunakan Pondok Pesantren Asy-Syamsiyah dalam mengatasi problematika yang ada, untuk mengetahui sistem manajemen peningkatan pengetahuan dan ketrampilan guru Pondok Pesantren Asy-Syamsiyah, untuk mengetahui peran Pondok Pesantren Asy-Syamsiyah dalam bimbingan potensi santri. Peneitian ini menggunakan metode penelitian kualitatif. Data yang di peroleh pada penelitian ini melalui observasi yaitu peneliti langsung meneliti dan mengikuti kegiatan yang ada di Pondok Pesantren As-Syamsiyah Denpasar Bali, wawancara yaitu peneliti mewawancarai guru, pengurus, dan santri yang ada di pondok pesantren, dokumen di dapat dari buku administrasi yang ada di kantor, foto dan dokumen-dokumen lainnya. Penelitian ini menunjukkan bahwa kompetensi yang dimiliki oleh guru masih sangat kurang dengan kurangnya pelatihan dan pendidikan, kurangnya pendidikan formal guru yang dapat memengaruhi dalam mengelola manajemen. Dalam mengembangkan potensi santri, guru memberikan pelatihan sesuai dengan bakat yang dimiliki santri di luar jam pembelajaran aktif.
\end{abstract}

Alamat Korespondensi:

E-mail: hafidul.muhsin@pasca.undiksha.ac.id (Hafidul Muhsin)

\section{Pendahuluan}

Dalam setiap perjalanan sebuah lembaga itu tidak terlepas yang nama aktivitas managemen karena setiap lembaga organisasi dan termasuk pondok pesantren selalu berkaitan dengan usaha-usaha mengembangkan dan memimpin suatu tim kerja sama atau kelompok orang dalam satu kesatuan dengan memanfaatkan sumber daya yang ada. Semua ini untuk mencapai suatu tujuan tertentu dalam organisasi yang ditetapkan sebelumnya.

Permasalahan seputar pengembangan model pendidikan pondok pesantren dalam hubungannya dengan peningkatan kualitas sumberdaya manusia (human resources) merupakan isu aktual dalam arus perbincangan kepesantrenan kontemporer.Maraknya perbincangan mengenai isu tersebut tidak bisa dilepaskan dari realitas empirik keberadaan pesantren dewasa ini yang dinilai kurang mampu mengoptimalisasi potensi yang dimilikinya. Setidaknya terdapat dua potensi besar yang dimiliki pesantren yaitu potensi pendidikan dan pengembangan masyarakat.

Pesantren dapat dikatakan kalah bersaing dalam menawarkan suatu model pendidikan kompetitif yang mampu melahirkan out put (santri) yang memiliki kompetensi dalam penguasaan ilmu 
dan sekaligus skill sehingga dapat menjadi bekal untuk terjun ke dalam kehidupan sosial yang terus mengalami percepatan perubahan akibat modernisasi yang ditopang kecanggihan sains dan teknologi. Kegagalan pendidikan pesantren dalam melahirkan sumberdaya santri yang memiliki kecakapan dalam bidang ilmu-ilmu keislaman dan penguasaan teknologi secara sinergis berimplikasi terhadap kemacetan potensi pesantren kapasitasnya sebagai salah satu agents of social change dalam berpartisipasi mendukung proses transformasi sosial bangsa melalui pembangunan nasional.

Masih banyak pesantren yang mempertahankan sitem pendidikan tradisional dan konvensional dengan membatasi diri pada pengajaran kitab-kitab klasik dan pembinaan moral keagamaan semata.Pesantren model pure klasik/salafi ini memang unggul dalam melahirkan santri yang memiliki kesalehan, kemandirian (dalam arti tidak terlalu tergantung kepada peluang kerja di pemerintahan) dan kecakapan dalam penguasaan ilmu-ilmu keislaman.Kelemahannya, out put pendidikan pure salaf kurang kompetitif dalam percaturan persaingan kehidupan modern.Padahal, tuntutan kehidupan global menghendaki kualitas sumberdaya manusia terdidik dan keahlian dalam bidangnya. Realitas out put pesantren yang memiliki sumberdaya manusia kurang kompetitif inilah yang kerap menjadikannya termarginalisasikan dan kalah bersaing dengan out put dari pendidikan formal baik agama maupun umum.

Kurangnya Sumber Daya Manusia (SDM) yang berkualitas merupakan akar dari semua persoalan bangsa kita dewasa ini.Untuk mengatasi permasalahan tersebut, maka harus diambil langkah-langkah jangka panjang seperti, membangun dan mengembangkan mental SDM yang mandiri, dan berjiwa kompetitif.Pendidikan merupakan salah satu sarana mewujudkan upaya pengembangan SDM tersebut.Oleh sebab itu pemerintah perlu menjadikan aspek pendidikan sebagai prioritas utama dalam merencanakan program kerja pembangunan kedepan. Beberapa hal yang bisa dilakukan oleh pemerintah adalah dengan menaikkan anggaran pelaksanaan pendidikan di wilayah-wilayah yang sedang berkembang serta melakukan evaluasi terhadap program pendidikan yang telah dilaksanakan, guna menemukan kelemahan pelaksanaan pendidikan masa sekarang dan menemukan jalan terang terhadap penyusunan kebijakan pengembangan pendidikan ke depan (Arifin, 1993).

Manajemen pendidikan pesantren merupakan suatu permasalahan tersendiri, karena selama ini pesantren identik dengan pendidikan milik kyai yang tidak memerlukan pengembangan ke arah masa depan yang lebih maju. Sementara itu, pada kenyataannya dunia pendidikan pesantren menjadi salah satu lembaga alternatif dalam menetralisasi globalisasi, sehingga tuntutan terhadap pengembangan manajemen pendidikan pesantren merupakan hal yang penting.

Manajemen Pondok Pesantren Asy-Syamsiyah Denpasar Bali yang meliputi manajemen pengetahuan dan ketrampilan guru Pondok Pesantren yang digunakan dalam meningkatkan mutu pendidikan. Problematika yang ada pada manajemen dalam peningkatan mutu pendidikan Pondok Pesantren Asy-Syamsiyah Denpasar Bali.Masalah yang diangkat dalam penelitian ini adalah (1) Bagaimana strategi yang digunakan Pondok Pesantren Asy-Syamsiyah Denpasar Bali dalam mengatasi problematika yang terjadi?; (2) Bagaimana Pola sistem manajemen peningkatan pengetahuan dan ketrampilan guru Pondok Pesantren Asy Syamsiyah Denpasar Bali?; (3) Bagaimana peran Pondok Pesantren Asy-Syamsiyah Denpasar Bali dalam bimbingan potensi santri?

\section{Metode}

Penelitian ini menghendaki kondisi sesungguhnya (natural/alamiah) yang ada pada suatu objek penelitian di mana peneliti adalah sebagai instrumen kunci (Arikunto, 2009; Moleong, 2000).Penelitian ini tidak melakukan percobaan-percobaan karena merupakan penelitian yang kondisional.Penelitian ini mengandalkan pengamatan, berperan serta dan wawancara bebas dan mendalam sebagai instrumen, sehingga menghasilkan data deskriptif, yang berupa kata-kata tertulis atau lisan dari orang atau prilaku orang yang diamati/yang terlibat dalam pengelolaan pengelola Pondok Pesantren.

Dalam penelitian ini pengambilan data diperoleh dengan cara wawancara. Dengan metode ini peneliti dapat berinteraksi atau bertatap muka dengan objek maupun subjek penelitian, sehingga akan didapatkan data yang akurat. Observasi merupakan penelitian langsung yang dilakukan peneliti.Peneliti terjun langsung ke dalam lingkungan Pondok Pesantren Asy-Syamsiyah, sehingga peneliti melihat langsung realita yang terjadi di Pondok Pesantren tersebut. Dokumen didapatkan dari arsip yang ada di kantor Pondok Pesantren, dengan dokumen peneliti mengetahui silsilah dan sejarah yang tertulis.Keabsahan data merupakan konsep penting yang diperbaharui dari konsep kesahihan data (validitas) dan keandalan (realibilitas) menurut aliran postivisme.Dalam pandangan aliran naturalistik tidak menggunakan istilah tersebut kepercayaan yang berbeda mengarah tuntutan pengetahuan (knowledge) dan kriteria yang berbeda.Pendefinisian kembali itu mengarah pada tekhnik control 


\title{
Hasil dan Pembahasan
}

\section{Hasil Penelitian}

\section{a. Latar Belakang Lahirnya Pondok Pesantren Asy-Syamsiyah Denpasar Bali}

Pada tahun 1990 disuatu tempat ada pengajian kecil yaitu pengajian al-Qur'an yang terdiri dari keluarga terutama cucunya Bapak Haji Syamsi, sedangkkan yang menjadi pengajar pada waktu itu adalah menant dari Bapak Haji Syamsi yang bernama Haji Ghufron. Sejak itu sampai lima tahun berjalan, seiring dengan berjalannya kegiatan pengajian kecil itu, menjadi semakin berkembanglah kegiatan itu dan sampai akhirnya dibutuhkanlah tenaga pengajar lain yang bisa menghandel atau melayani anak-anak santri. Lalu didatangkanlah seorang guru Agama Islam dari Kantor Departemen Agama yang bernama Bapak Drs.Abdul Halim, beliau mengajar ngaji disana selama lima tahun atau sampai tahun ke- 2000. Selanjutnya tuan rumah (Bapak Haji Syamsi) pergi ke Pasuruan (Jawa Timur) untuk mencari tenaga pengajar yang handal dari unsur Pondok Pesantren yang terkenal yaitu alumnus Sidogiri-Pasuruan-Jawa Timur, dan alhamdulillah niat baik pak haji disambut baik oleh sang kyai dan akhirnya diutuslah salah satu santri terbaiknya yang bernama Ustadz Fuadi untuk membantu berdakwah, bersyiar di rumah Bapak Haji Syamsi.

Sejak di asuh dan di ajar oleh Ustadz Fuadi, santri-santri yang tadinya hanya berjumlah sepuluh anak dari keluarga pak Haji Syamsi, maka semakin hari semakin banyak berdatangan santri-santri yang lain, karena minat dan semangat belajar mengaji anak-anak semakin maju, maka dirubahlah komunitas pengajian kecil itu menjadi TPQ (Taman Pendidikan al-Qur'an) pada tahun ke- 2002 dan diberi nama dengan TPQ As-Syamsiyah.

Sejak dibuka dan diresmikannya TPQ As-Syamsiyah, semakin terus bertambahlah jumlah santri yang mengaji disana hingga mencapai seratus anak/100 santri dengan di asuh oleh enam pengajar/6 ustadz yang semua dari alumnus Pondok Pesantren Sidogiri Pasuruan Jawa Timur.

Dua tahun TPQ As-Syamsiyah berjalan, dan terus menerus jumlah santri semakin bertambah, maka dibangunlah gedung baru seluas 2 are dengan 3 lantai untuk penambahan lokal tempat belajar mengaji para santri dan selesailah bangunan itu pada tahun 2004. Setelah berjalan kurang lebih dua tahun atas kesepakatan tuan rumah (Bapak Haji Syamsi), para ustadz, wali santri, para tokoh masyarakat setempat, dan izin restu dari Kantor Departemen Agama maka didirikanlah Pondok Pesantren AsSyamsiyah pada tahun 2007 dengan menunjuk Ustadz Fuadi dari alumnus Pondok Pesantren SidogiriPasuruan sebagai Pengasuh tunggal.

Dalam perkembangan selanjutnya, makin banyak santri mulai dari yang kecil hingga dewasa berdatangan untuk menuntut ilmu dan belajar di Pondok Pesantren ini dan sampai sekarang di tahun ke2012 data santri (putra-putri) keseluruhan mencapai kurang lebih sekitar 370 santri. Di Pondok Pesantren ini aktifitas santri tidak hanya belajar ilmu agama saja tetapi juga ilmu-ilmu umum (melalui kegiatan bimbel atau bimbingan belajar) serta kegiatan sosial kemasyarakatan.

Demikianlah hingga sekarang keberadaan Pondok Pesantren As-Syamsiyah yang terletak di Jalan Ahmad Yani (Kampung Jawa) Desa Wanasari - Denpasar Barat, telah menjadi kebanggaan tersendiri bagi masyarakat disana dan umumnya warga muslim Denpasar.

\author{
b. Daftar kepengurusan Pondok Pesantren Asy-Syamsiyah Denpasar Bali \\ Pelindung : Kepala Dusun dan RT \\ Ketua Umum : Bapak Haji Budi \\ Penasihat : Bapak Haji Munir dan Bapak Drs. Supardi \\ Ketua I : Bapak M. Sugeng \\ Ketua II : Bapak Haji Edi \\ Ketua III : : Bapak Haji Sugi \\ Ketua IV : Bapak Haji Yanto \\ Sekretaris I : Bapak M. Juarno \\ Sekretaris II : Bapak Sukri \\ BendaharaI :Bapak H. Kadarisman \\ Bendahara II : Bapak Abdil Aziz \\ Pengasuh Ponpes: Ustadz Mustofa \\ Kepala TPQ : Ustadz Nurul Huda \\ Kepala Madin : Ustadz Izzuddin
}




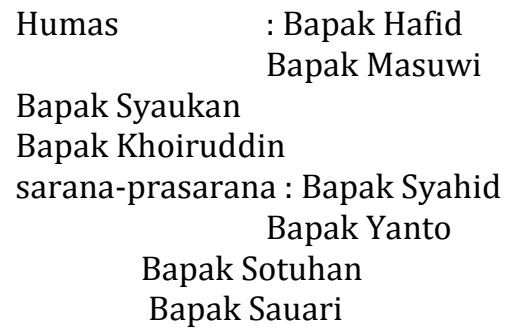

\section{c. Data Para Pengajar/Ustadz-Ustadzah Pondok Pesantren As-Syamsiyah DenpasarBali 2007-Sekarang}

1) Ustadz Musthofa

2) Ustadz Izzuddin

3) Ustadz Muzawi

4) Ustadz Nurul Huda

5) Ustadz Muhammad Sholeh

6) Drs.Ustadz Supardi

7) Ustadz Yanto

8) Ustadz Qosim

9) Ustadzah Maimunah, S.Pd I

10) Ustadzah Suniah

11) Ustadzah Ely Hikmawati

12) Ustadzah Sumiyati

13) Ustadzah Fitriana ( TU)

14) Ustadzah Elok (TU)

\section{d. Sarana-prasarana Pondok Pesantren As-Syamsiyah Denpasar - Bali}

Salah satu yang memegang peranan penting dalam kelancaran proses belajar mengajar dan peningkatan prestasi akademik adalah sarana dan prasarana pendidikan. Sarana dan prasarana yang disediakan oleh Pondok Pesantren As-Syamsiyah Denpasar Bali adalah :
1) Gedung 3 lantai
2) Ruang kelas 12 ruangan
3) Kamar mandi 5
4) Kantor 1
5) Koperasi 1
6) Kamar santri 3
7) Musolla 1

Proses pelaksanaan manajemen pendidikan Pondok Pesantren As-syamsiyah Denpasar Bali tidak terlepas dari proses manajemen pendidikan secara umum. Adapun pengelolaan dalam menjalankan manajemen pendidikan Pondok Pesantren As-syamsiyah Denpasar Bali. Dalam manajemen kesantrian fihak yang perlu diperhatikan dalam membuat rencana adalah kondisi pengurus pondok pesantren sebagai penanggung jawab tertinggi, kondisi ustadz pembimbing yang akan dilibatkan dalam kegiatan kesantrian, kondisi siswa / santri, dan kondisi orang tua siswa / santri. Secara sistematis perencanaan dalam manajemen pendidikan pondok pesantren adalah merencanakan untuk melaksanakan kegiatan : menganalisis daya tampung santri, penerimaan santri baru (PSB), orientasi santri baru, pengelompokan santri, pembinaan kegiatan pendidikan pondok pesantren, penyediaan sarana prasarana dan pengkoordinasian alumni pesantren.

Dalam rangka meningkatkan sumber daya tenaga pengajar di Pondok Pesantren As-Syamsiyah Denpasar Bali, maka pihak pesantren harus mampu memilih dan memilah kualitas keilmuan calon tenaga pengajar yang akan diterjunkan di pondok pesantren.Berdasarkan observasi, hasil penelitian yang didapat adalah semua Ustadz di Pondok Pesantren Asy-Syamsiyah Denpasar Bali merupakan alumni Pondok Pesantren Sidogiri Pasuruan Jawa Timur yang sudah terbiasa digembleng untuk menjadi pendidik pada Pondok Pesantren.Dalam bimbingan potensi santri, para ustadz atau ustadzah di Pondok Pesantren AsySyamsiyah Denpasar Bali memberikan pelatihan-pelatihan khusus sesuai dengan bakat masing-masing santri.

\section{Pembahasan}


Unsur utama dalam manajemen adalah pendayagunaan, kerja sama, pengorganisasian dan tujuan dan target yang direncanakan. Dalam organisasi pendidikan pondok pesantren, pengasuh atau pemilik pondok pesantren yang berperan sebagai manajer bertugas untuk mengorganisir seluruh staf yang ada dilingkungan pesantren untuk diperdayakan sesuai kemampuan dan tugas yang di berikan menurut sasaran yang ditetapkan. Biasanya tujuan dan sasaran yang hendak dicapai adalah penjabaran dari visi dan misi pondok pesantren tersebut.Namun kenyataannya pada Pondok Pesantren Asy-Syamsiyah Denpasar kurang dalam berkoordinasi antara pengasuh dan guru.Semua pengelolaan diserahkan sepenuhnya kepada para guru.Dalam penerimaan santri baru yang kurang efektif dengan tidak adanya panitia khusus.Dan tidak adanya seleksi dalam rekruitmen guru.

\section{b. Kompetensi Guru}

Melihat tanggungjawab guru yang sangat besar tersebut maka guru yang ideal itu harus memiliki kompetensi untuk membimbing dan mengarahkan siswa agar mencapai hasil yang optimal (Azyumardi, 2000). Besar kecilnya peranan guru akan tergantung pada tingkat kompetensi yang dimilikinya (Depag RI, 2003). Kalau penulis melihat di lapangan sesuai dengan studi pendahuluan yang telah dilakukan di Pondok Pesantren Asy-Syamsiyah Denpasar, bahwasanya guru Pendidikan Agama Islam masih jauh dari konsep guru yang ideal, karena mereka dinilai kurang berkompeten dalam pelaksanaan pembelajaran, sehingga proses belajar kurang maksimal dan jauh dari yang diharapkan.

Tingkat pendidikan formal guru di Pondok Pesantren Asy-Syamsiyah Denpasar masih terasa kurang memadai.Mereka rata-rata berpendidikan SMA.Namun, pendidikan kepesantrenan sudah cukup memadai karena guru-guru di Pondok Pesantren Asy-Syamsiyah adalah para alumni Pondok Pesantren Sidogiri Pasuruan Jawa Timur. Padahal, tingkat pendidikan memiliki pengaruh terhadap hasil sebuah proses pembelajaran (Sedarmayanti, 2001).

Pesantren salafiah biasanya tidak didukung oleh guru dalam jumlah besar. Dalam memenuhinya sering mendapatkan kesulitan karena keterbatasan dana untuk menggaji mereka. Atas dasar inilah perlu diupayakan cara peningkatan kualitas mereka secara lebih ekonomis, dengan tujuan bagaimana guru yang sedikit dapat memiliki kinerja yang tinggi sehingga pesantren tetap mampu memberi pelayanan pendidikan dan pengajaran yang optimal kepada santri dan masyarakat. Salah satu upaya peningkatan mutu guru tersebut adalah membekali keterampialn teknis dan konseptual melalui mentoring, kepelatihan (coaching) dan praktek.Ketiga teknik peningkatan keterampilan guru di atas patut dipertimbangkan mengingat karakteristiknya yang relefan dengan karakteristik kehidupan pesantren, yakni kolegial, komunikatif, demokratis dan humanistik.Selain itu, metode tersebut ternyata telah diterapkan di pondok-pondok salafiah sejak dahulu. Sejalan dengan ilmu-ilmu moderen, cara tersebut sejalan dengan prinsip-prinsip supervisi pendidikan, yang mengandung fungsi-fungsi supervisi, pemberdayaan dan transformatif. Oleh karena itu, bagaimana pengasuh pesantren memelihara dan mengembangkan teknik-teknik tersebut sebaik mungkin.Para guru Pondok Pesantren Asy-Syamsiyah Denpasar belum pernah mengikuti pendidikan dan pelatihan guru pada pondok pesantren, dan belum pernah mengadakan studi banding ke pesantren lainnya.

\section{c.Bimbingan Potensi Santri}

Beberapa metode pengembangan skill santri adalah Nadwah (Diskusi) metode pembelajaran disampaikan dalam bentuk diskusi (pemecahan masalah) yang melibatkan ustadz dan santri sebagai nara sumber dan peserta dengan melakukan tukar pikiran dan pengalaman sesama santri mengenai kasus atau masalah yang menjadi tema pembahasan. Ta'lim Bil-lu'bah (Simulasi) program pendidikan diberikan dalam bentuk permainan/simulasi, studi kasus atau olah peran, yaitu pendalaman materi melalui pengendalian diri kehidupan yang nyata (sebenarnya). Uswatun Hasanah (Pemodelan) materi disampaikan dengan menghadirkan tokoh-tokoh panutan yang secara signiifikan telah berhasil dan dapat menjadi contoh/suri tauladan dalam kehidupannya.

Santri Pondok Pesantren Asy-Syamsiyah di bekali dengan ketrampilan sesuai dengan bakat dan potensi yang dimiliki masing-masing santri. Guru memberikan pengembangan skill kepada mereka diluar pelajaran efektif, sehingga tidak mengganggu proses pembelajaran. Keberhasilan pengembangan skill ini dapat dilihat dari prestasi yang di raih oleh para santri mulai dari tingkat kota hingga ke tingkat Nasional.

\section{Simpulan}

Manajemen Pondok Pesantren Asy-Syamsiyah Denpasar Bali masih menggunakan manajemen tradisional.Dalam mengelola masih di dominasi oleh pemilik tanah atau pesantren, walaupun pengelolaan pembelajaran seluruhnya diserahkan kepada para ustad.Pada Pondok Pesantren Asy-Syamsiyah tidak adanya menejemen yang ideal, namun tidak mempengaruhi proses belajar mengajar di Pondok Pesantren 
Asy-Syamsiyah dan prestasi yang di hasilkan (out put-nya).Kompetensi Guru Pondok Pesantren AsySyamsiyah dirasa masih jauh dari kata ideal. Dikarenakan lemahnya inovasi dan kreatifitas tenaga pengajar pada pondok pesantren dapat ditingkatkan dengan mengadakan diskusi secara intern antar pengurus dan tenaga pengajar diadakan pelatihan manajemen pendidikan dan metodologi pengajaran, sehingga dengan inovasi sistem pengajaran yang dilakukan oleh guru akan membuat santri betah dan daya serapnya terhadap materi pembelajaran akan maksimal.Prestasi adalah merupakan tolak ukur sejauh mana mutu kualitas didalam pendidikan itu berupaya untuk merealisasikan sebuah misi yang ada dalam aturan, mandat atau amanah yang mereka usung.

\section{Referensi}

Arikunto,Suharsimi. (2009). Manajemen Penelitian. Jakarta: Aneka Cipta.

Arifin.(1993). Kepemimpinan Kyai Dalam System Pengajaran Kitab-Kitab Klasik (Studi Kasus di Pondok Pesantren Tebuireng Jombang). Malang: Kalimasada.

Azra, Azyumardi. (2000). Pendidikan Islam, Tradisi dan Modernisasi Menuju Millenium Baru. Jakarta: Logos.

Depag RI. (2003). Pola Pembelajaran Di Pesantren. Jakarta.

Moleong, J.Lexy. (2000).Metodologi Penelitian Kulaitatif. Bandung: PT.Remaja Rosdakarya.

Sedarmayanti.(2001). Sumber Daya Manusia dan Produktivitas Kerja. Bandung: Mandar Maju. 